\title{
MODELS IN SCIENCE COMMUNICATION POLICY
}

\author{
Formatting Public Engagement and Expertise
}

by Per Hetland

\begin{abstract}
Three models of expert-public interaction in science and technology communication are central: the dissemination model (often called the deficit model), the dialogue model, and the participation model. These three models constitute a multi-model framework for studying science and technology communication and are often described along an evolutionary continuum, from dissemination to dialogue, and finally to participation. Underlying this description is an evaluation claiming that the two latter are "better" than the first. However, these three models can coexist as policy instruments, and do not exclude each other. Since 1975, concerns with public engagement over time have led to a mode that is more dialogical across the three models within science and technology communication policy in Norway. Through an active policy, sponsored hybrid forums that encourage participation have gradually been developed. In addition, social media increasingly allows for spontaneous public involvement in an increasing number of hybrid forums. Dialogue and participation thus have become crucial parts of science and technology communication and format public engagement and expertise.
\end{abstract}




\section{Introduction}

Although several authors have aimed to analyze science and technology communication in Norway from a broader perspective (Andersen and Hornmoen 2011, Bentley and Kyvik 2011, Kyvik 2005, Lovhaug 2011), there is no thorough analysis of Norwegian science and technology communication policy framing those activities. Consequently, the present paper aims to study Norwegian science and technology communication policy and how it has evolved since 1975. In a Norwegian context, the emphasis on the communications of science and technology was expanded and strengthened in 2003, in the revised "Act Relating to Universities and University Colleges," where it was declared that higher education institutions have three assignments: education, scientific research, and public communication of science and technology. Consequently, public communication of science and technology is sometimes called the third assignment. The third assignment should: 1) contribute to science and technology communication; 2) contribute to innovation; and 3) ensure the participation of staff in public debate.' We know from studies of the third assignment in Sweden that the assignment was understood both within a dissemination model as well as in more dialogical models (Kasperowski and Bragesjö 2011).

The sectoral principle has been fundamental to Norwegian science and technology policy since 1972 (Skoie 2005:67). In keeping with this principle, each of the 15 ministries in Norway has an overall responsibility for research in and for its specific sector, whereas the Ministry of Education and Research has a role in coordinating national policy. When it comes to science and technology communication policy, several other ministries have crucial roles, especially when it comes to user-oriented science and technology communication. Further, the Ministry of Local Government and Modernisation is responsible for the central government communication policy. The underlying principle for central government information and later communication policy in Norway has progressed from the publicity principle (Informasjonsutvalget 1962) to the principle of public information (FAD 1978), and from there to the communication principle (AAD 1202), culminating in the principle of participation (FAD 2002). The principle of communication implies that public authorities engage in two-way symmetric communication with the citizens with the purpose of achieving mutual understanding, whereas the participation principle implies that public authorities shall take advice from affected citizens and involve them in the shaping of policies and services. Dialogue and participation are consequently growing more important within central government communication activities, and this development is a crucial backdrop for how science and technology communication policy has evolved since 1975.

Three models of expert-public interaction in science and technology communication are suggested by Bucchi and Trench: the dissemination model (often called the deficit model), the dialogue model, and the participation model (Bucchi 2000, Trench 2008). As both Bucchi and Trench emphasize, these three models can coexist as policy instruments, and they do not exclude each other. Concerns with public engagement over time have led to a more dialogical mode across the three models. This paper uses Norwegian science and technology communication policy as an example. The aim of the paper is twofold: 1) to substantiate that the dialogical turn cuts across all of the three communication models, and 2) to study how each model facilitates the transformation from engagement to the acquirement of different kinds of expertise among the participants (Collins and Evans 200z). In Norway, the concept "science communication" includes also the communications of social sciences and humanities. For simplicity, when referring to the communications of science and technology the abbreviated terms communication of science or science communication are used throughout the paper. All translations from Norwegian to English have been done by the author. In the following section, I present a typology of how public engagement and expertise are formatted.

\section{Theoretical and conceptual issues}

The quest for dialogue and participation stems from two interrelated discourses: the first concerning public understanding of science, and the second based on the discourse on the new production of knowledge. To begin with, the vocabulary of public understanding of science has changed over the last two decades (Suerdem et al. 2013). Concern with public engagement has led to a shift from the dissemination model to more dialogical models. Suerdem et al. present a lexicographic and bibliometric study of the journal Public Understanding of Science over the last 20 years, in which they conclude that "the theoretical topics shift from modelling public understanding to formatting public engagement" (p.13).
The discourse on the new production of knowledge is concerned with new features such as transdisciplinarity, heterogeneity, the extended peer community, and the new dynamic relationship between society and science (Gibbons et al. 1924, Leydesdorff and Etzkowitz 1298, Nowotny, Scott, and Gibbons 2001, Funtowicz and Ravetz 1222). This discourse is prominent in science and technology studies, as well as in innovation studies. Concepts such as Triple Helix, Mode 2, and Science 2.0 are all concepts central to understanding the new production of knowledge.

The dissemination model is often perceived as a simple transfer

1.http://www.lovdata.no/all/nl-20050401-015.html 
model where knowledge is communicated by experts to various publics in an attempt to enlighten the same publics. The muchused concept for the same model in science communication, the deficit model, can be traced back to the work of C. P. Snow (19626), which claims that there is one split between the natural sciences and the humanities, and one split between the natural sciences and their applications. In his understanding of science and socioeconomic development, Snow applies a linear diffusion of innovations model that also underpins the deficit model. The deficit may be overcome or the diffusion of innovations may take place only if the public is educated or enlightened. The deficit model, as well as the linear diffusion of innovations model has therefore been the object of much criticism (Eagerberg. Mowerv, and Nelson 2005, Hetland 1296, Irwin and Michael 2003). The criticism of the deficit model is strongly linked to the dominant view of science popularization as downstream representations (Hilgartner 1220). The press seems to constitute the most important "intermediary communication device" in this respect (Le Marec and Babou 2008:4.2). Bech-Karlsen offers a suggestion as to how the enlightenment tradition may be understood in different contexts. In defense of the enlightenment tradition, Bech-Karlsen points to the basic distinction between the Nordic and continental European traditions. "The Nordic variant is based upon a dialogue and respect for the recipient's values, while the European model regards the recipient as 'an empty container' which shall be filled with knowledge" (Bech-Karlsen 1206:22). Bech-Karlsen supplements this by describing the classic European tradition as a transfer of knowledge from the expert to the layperson. In the Nordic tradition, the expert enters into a dialogue with the layperson. Bech-Karlsen maintains that there is nothing principally authoritative within the enlightenment tradition, but rather the authoritative aspects are temporary and circumstantial. A similar argument is made by Broks and Perrault when they present the CUSP model or Critical Understanding of Science in the Public (Broks 2006, Perrault 2012). Within dissemination activities, Perrault identifies three models, Public Appreciation of Science and Technology (PAST), Public Engagement with Science and Technology (PEST), and CUSP. She uses the three models to study how researchers and journalists frame their popularization activities. Her main point is that "popular science writing can and should contribute to civic engagement" (p. 8) and thereby empower readers. The CUSP model aims to resolve the "lingering deficit model characteristics by suggesting a kind of science communication that considers all the elements of science-in-society, including their interactions, to be worth scrutinizing" (p. 15).

Increasingly, dissemination is also perceived as an important activity when applying for research funding: media exposure is made into an indicator of social relevance. This is also reflected in the change from the slogan "publish or perish," to "be seen in public or perish" (Väliverronen 1223). In Norway, about half of the faculty published at least one popular science article during a three-year period, whereas six percent of the faculty published half of all popular science articles (Kvvik 2005). The changes affect not only faculty members. Public relations personnel of academic institutions are also incorporated into the dissemination process (Bauer and Bucchi 200z, Nelkin 1225). Consequently, personnel experience a convergence between the policy for dissemination of science and institutional public relation activities.

In spite of the growing literature on dialogue and participation, there are few distinct definitions that strictly separate the two concepts (Bucchi 2002, Bucchi and Trench 2008, Callon, Lascoumes, and Barthe 2009). Therefore, I treat the three communication models as part of a continuum, which is best described along two dimensions:1) the intensity of cooperation among different actors in knowledge production processes and 2) the extent to which public participation is elicited by a sponsor (Bucchi 2002) (see Figure 1).

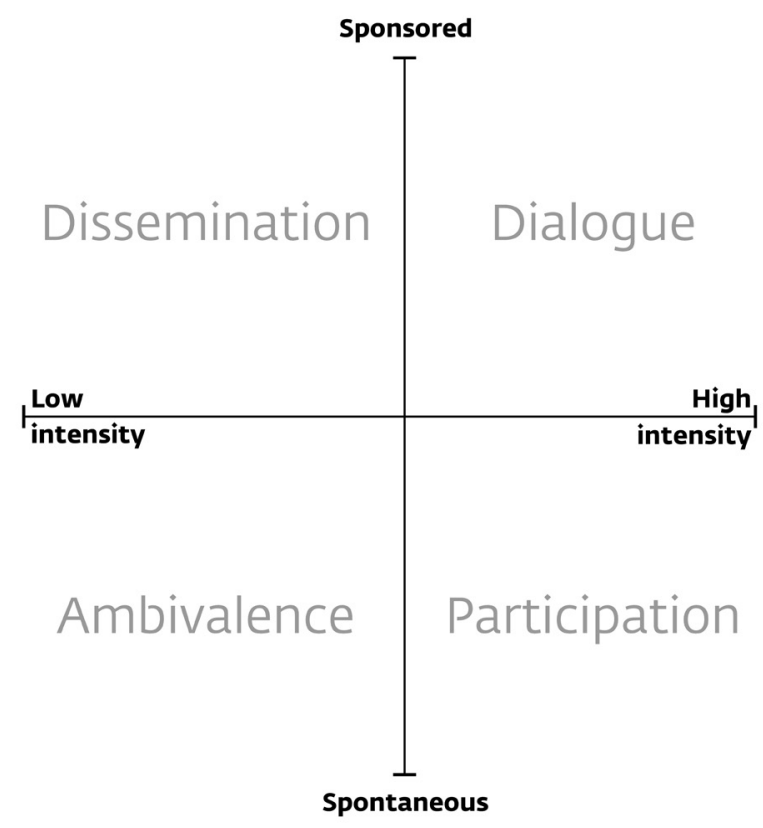

Figure 1. Participation forms for users and the public. Source: Modeled after Bucchi 2009:66 The upper-left quadrant illustrates policy measures within the dissemination model. As already indicated by Bech-Karlsen, the space for a more active role may be larger within the Nordic tradition than it is within the classic European tradition. The upper-right quadrant represents policy measures within the dialogue model. Within the dialogue quadrant, one is able to bridge the single delegation, that is the delegative democracy or traditional representative democracy (Callon 1229, Callon, Lascoumes, and Barthe 2002). The lowerright quadrant represents policy measures within the participation model. Within the participation quadrant, one is able to bridge the double delegation, that is the delegative democracy and the secluded science by which society entrusts specialists. To encourage science and technological development and democratic participation, Callon et al. emphasize the significance of hybrid forums that permit new forms of political participation and broader insight and influence compared to the central ethical dilemmas existing within science and technological development. Hybrid forums provide 
opportunity for a broad number of actors who wish to contribute to the development of science and technology, and those who are involved constitute a heterogeneous group of actors, including experts, politicians, technologists, and lay people, simultaneous to the themes that are taken up cut across traditional boundaries. However, it is not always clear what participation implies (Delgado, Kiglberg. and Wickson 2011). Delgado et al. identify five "topics of tension" when applying the concept of participation. These can be formulated as the following questions:1) Why should the public participate? 2) Who should be involved? 3) How should it be initiated? 4) When is the right time to do it? 5) Where should it be grounded? (p. 828). I return to these tensions later in the text.

Finally, there is the "science and technology ambivalence" quadrant. Science and technology ambivalence is a rather heterogeneous category, including motivated rejection, conspiracist responses, pseudoscience, ideology, and faith (Gieryn 1222, Lewandowsky. Oberauer, and Gignac 2013). The category is an important reminder that disengagement with science in the traditional sense is not necessarily the obverse of engagement (Brint and Cantwell 2012).

Central to the three models are the various forms of expertise, and the fact that the public "remains a relatively under-theorized doxa shared by both advocates and critics of the public deficit model" (Hess 2017:628). Understanding the different publics and their roles is consequently paramount for a better understanding of what differentiate the three communication models (Braun and Schultz 2010). Collins and Evans approach science communication through an attempt to map the diversity of expertise. They start from the view that "expertise is the real and substantive possession of groups of experts and that individuals acquire real and substantive expertise through their membership of those groups" (p. 2-3). All of us possess that which we call ubiquitous tacit knowledge, either in the form of 1 ) "beer-mat knowledge" (without a deeper insight into why it works); 2) popular understanding; and/or 3) primary source knowledge. Concerning specialist tacit knowledge, Collins and Evans distinguish between contributory expertise and interactional expertise (i.e., expertise required to manage a field of knowledge through interaction but does not contribute to the field). With this as the point of commencement, they attempt to develop a periodic table for expertise. Along the expertise dimension the table is constructed around, Collins and Evans refer to specialist expertises and meta-expertises. Along the knowledge dimension, one proceeds from basic knowledge (which we all have) to highly specialized knowledge (which only a few acquire). Their project contributes to a clarification of expertise as a social phenomenon and is crucial to a better understanding of the three communication models.

Finally, one problem needs to be mentioned: the relationship between models people claim to use and what they actually do. As Brossard and Lewenstein (2010) document in an assessment of how real-world outreach activities accord to the theoretical models, most outreach activities tend to use the dissemination model as a backbone, even if they claim to do something different. Consequently, the present study of models in science communication policy is primarily a study of the policy that frames science communication, not a study of how science communication is actually performed.

\section{Method}

In the next section, I provide a review of how Norwegian science is a content analysis of nine white papers presenting science policy, communication policy has developed since 1975 . The empirical basis and one white paper presenting innovation policy (see Table 1).

\begin{tabular}{|l|l|l|}
\hline White Paper Science Policy & Title & Responsible Minister \\
\hline St.melding nr. 35 (1975-1976) & $\begin{array}{l}\text { Om forskningens organisering og finansiering } \\
\text { [The organization and financing of research] }\end{array}$ & Bjartmar Gjerde, Labour Party \\
\hline St.melding nr. 119 (1980-1981) & $\begin{array}{l}\text { Om utviklingen i forskningens organisering og finansiering } \\
\text { [Developments in the organization and financing of research] }\end{array}$ & Einar Førde, Labour Party \\
\hline St.melding nr. 60 (1984-1985) & Om forskningen i Norge [Research in Norway] & Lars Roar Langslet, Conservative Party \\
\hline St.melding nr. 28 (1988-1989) & Om forskning [On research] & Hallvard Bakke, Labour Party \\
\hline St.melding nr. 36 (1992-1993) & Forskning for fellesskapet [Research for the common good] & Gudmund Hernes, Labour Party \\
\hline St.melding nr. 39 (1998-1999) & Forskning ved et tidsskille [Research at the beginning of a new era] & Jon Lilletun, Christian Democratic Party \\
\hline St.melding nr. 20 (2004-2005) & Vilje til forskning [Commitment to research] & Kristin Clemet, Conservative Party \\
\hline St.melding nr. 30 (2008-2009) & Klima for forskning [Climate for research] & Tora Aasland, Socialist Left Party \\
\hline Meld.St. 18 (2012-2013) & $\begin{array}{l}\text { Lange linjer - kunnskap gir muligheter } \\
\text { [Long-term perspectives - knowledge provides opportunity] }\end{array}$ & Kristin Halvorsen, Socialist Left Party \\
\hline St.melding no.7 (2008-2009) & Et nyskapende og bærekraftig Norge [A creative and sustainable Norway] & Sylvia Brustad, Labour Party \\
\hline Table 1 White papers presenting science policy and innovation policy & \\
\hline
\end{tabular}


For simplicity, I will refer to the years and the relevant page later in the text, except for the Innovation White Paper that will be referred to in full.

In the textual analysis, I have primarily done an ex-ante appraisal of the different policy measures that are proposed within science and technology communication (Rip 2003). However, most of the mentioned policy measures are implemented, and a short ex-post evaluation is included for some measures. Six of the science policy white papers together with the single innovation policy white paper have been presented by Labour Party-dominated governments. Three of the white papers have been presented by Conservative and Liberal governments. However, there is a large degree of consensus within Norwegian science and technology policy and consequently few examples of major disagreements. I have therefore not attached any importance to the party-political dimension in this respect. Studies concerning the science policy debate in the Nordic countries nevertheless show that science policy most often attracts only the interest of "immediate stakeholders and people with expert knowledge about the specific area" (Kallerud et al. 2011:76).

This paper, which is based on relevant policy papers, presents a study of policy. In contrast, another interesting approach has been to study the merits public communication of science gives within scientific institutions. From an earlier mapping we know that the qualification requirements for achieving competence within the higher education and research hierarchies have moved from a broader set of requirements, defined in 1970, to a more narrow definition of academic requirements from 1995 and onward (Finne and Hetland 2005). The change is also an important part of policy and practice; however, this point is beyond the scope of this paper.

The white papers and other relevant material are rich materials for analysis. Within each communication model, description is partly organized in a chronological manner; however, because the paper aims to explore crucial aspects of all three models for science communication used in Norwegian science communication policy a theoretical/conceptual organization has been chosen. The dissemination model as it is implied in the policy papers will be presented first. The Lasswell model - "Who (says) What (to) Whom (in) What Channel (with) What Effect" is a well-known dissemination model of communication, and, as such, it may be used to organize the description of the different policy measures within this model (Lasswell 1048). For the dialogue and participation models, the descriptions will be organized according to the central issues as described by Bucchi (2009) and Trench (2008). It is not possible to present the material in full, and the paper will only present some trends and illustrative examples.

\section{The dissemination model}

Regarding who, the center of gravity shifts from researchers and journalists in the first white papers (1975-1976:79 \& 1980-1981:47) to public relations and dissemination institutions in the later white papers (e.g., 2012-2013:36). The proposals to focus on the training of researchers and journalists must be seen in the light of the virtual absence of science journalism at that time (Eide and Ottosen 1224.). In addition, there were established awards based on excellent dissemination by researchers (1988-1989:69). One important problem was mentioned in two white papers, the question of whether the assessment criteria for academic positions took the question of dissemination seriously enough (1975-1976:79 \& 1988-1989:69); however, a more narrow definition of academic requirements was implemented in 1995, emphasizing academic production in international peer reviewed journals. There is also a growing interest in what the journalists and researchers are going to tell the public. In the mid-1990s, Erling Dokk Holm was the research coordinator of the Norwegian Research Council (NRC), and he suggested that the concept of science dissemination should be changed from "popularization" to "something more." The latter, somewhat indeterminate concept, implies a reorientation from "the end

product" to "process" ( a problem concerning the dissemination of provisional research findings, something that had been already mentioned in the 19751976 white paper: "Over the years, there have been many examples of uncritical dissemination of provisional research findings which possibly can have had good press value" (1975-1976:78). Attempts to solve the problem have been made employing Ingelfinger's rule, first presented by Franz J. Ingelfinger in 196 in The New England Journal of Medicine. In practice, Ingelfinger launched "an embargo designed to keep scientific findings out of the media until peer-reviewed and published" (Tov 2002:125). The most important policy measure was to establish the National Committees for Research Ethics in Norway in 1990 (1992-1993:113-117). The guidelines for the social sciences, humanities, law and theology as well as the guidelines for health and medicine entail rules in line with Ingelfinger's rule, whereas the corresponding research ethics rules for the natural sciences and technology do not refer to Ingelfinger's rule in the current regulations. ${ }^{2}$ Early in the new century, a proposal was launched whereby an "expert portal" (2004-2005:194) would be established to stimulate investigative multisource journalism 
concerning science (2004-2005:125), as an attempt to encourage the CUSP model. At the same time, the significance of public relations increased, and in the 2012-2013 white paper, it is emphasized that research results are also a "sales product" and that science dissemination is increasingly linked to the marketing of science and its results (2012-2013:36). The educational system is consequently understood as an important means for ensuring a knowledgeable public and a critical press.

Whom shall be considered as "the public" beyond the general public is unclear in the first white papers. The point of commencement was that if we were to succeed in engaging the public, then science journalism would have to be improved. The 1992-1993 white paper was the first to address the issue of which members of the public should be prioritized. The white paper specified that the NRC was to have the task of preparing a national strategy for science dissemination aimed at the public in general (1992-1993:154). In the national strategy (NFR 1292), the following overall objective is formulated: "Through a general dissemination of research, the aim is to encompass that part of the general public who are not traditional users of research simultaneous to including research in the public debate" (p. 7). Three main groups are defined as especially important: 1) Children and youth who will form the basis for recruitment of future researchers, 2) teachers, who are disseminators of research results to their pupils, and 3) journalists, who disseminate research and who, because of their position, can influence the science policy debate.

In addition, the same white paper states that the dissemination element should be incorporated as a systematic part of research programs and projects under the NRC (1992-1993:154). Dissemination was to be imperative. Information Director Paal Alme of the NRC writes: "In practice, if the researcher has made no attempt to disseminate state-funded research to the general public, this could result in exclusion or demands on refunding a grant" (Alme 1225). Even though such a regulation was never imposed, the statement is an expression of the increased importance attached to the dissemination activities.

The question of what channel is not made clear in the first white papers, whereas, at the same time, political measures and technological development resulted in an increased number of channels. The NRC, research institutions, and researchers comprise a three-dimensional structure that has a special responsibility for establishing innovative dissemination processes. A number of specific measures have been established or expanded, mentioned in several of the white papers, and in NFR 1997. The Norwegian Contest for Young Scientists commenced because of a private initiative as early as 1968 and grew in ambition and extent. The Nysgjerrigper Science Knowledge Project for children in primary schools was established in 1990. The Norwegian Science Week was inaugurated in 1995, during which year the Science Channel was established as a joint project incorporating the largest universities and university colleges with weekly transmissions by the
Norwegian Broadcasting Corporation. This activity came simultaneous to the launch of a number of other projects directed toward children and youth including TV series such as Newton. Forskning. no [Science.no] was established in 2002 as an online newspaper devoted to Norwegian and international science, including several possibilities for feedback and debate. By May 2014, the collaboration involved 80 research and educational institutions. The Science Centres Programme was established in 2003 as an important project, not least for stimulating the interest of youth in the STEMfields (science, technology, engineering, and mathematics). In May 2014, Norway had nine regional science centers and five additional specialized science centers. Further, it was important to strengthen museums' activities focused on schools. Both the museums and the science centers adopted social media to increase the possibility for inquiry-based learning. Finally, the Researcher Grand Prix was established in 2010.

In the 2004-2005 white paper, all state-financed research institutions are encouraged to develop their own dissemination strategies, and the Ministry was to develop a "dissemination indicator in the financial model for universities and university colleges" (2004-2005:128). Following two reports (UHR 2005, 2006), it was clear that there were larger problems than initially thought. In the first report, indicators were proposed for publication in popular (nonscientific) journals, feature articles in newspapers, popular science journals, student texts, lectures concerned with user-oriented specialist conferences, and other forms of dissemination to the general public. At the same time, there was an interest in stimulating R\&D knowledge via the Internet. In the second report, "innovation and interaction with the industry" were emphasized, in addition to many of the same activities mentioned in the first report. However, the proposed dissemination indicator was not implemented, although the institutions were encouraged to develop an active dissemination policy (2008-2009:129). In many respects, it can be claimed that the dissemination indicator in the financial model was "dead in the water" when the number of channels increased and that which it was desired to measure had become difficult to measure.

What should be the results of science communication? Central to the 1975-1976 white paper was the need to disseminate information on the scope and limitation of science, such that as many people as possible would be able to evaluate the significance of science (19751976:77). The support of the public is thus considered an important assumption for a well-functioning science policy. Whether public support is a result of dissemination is not known, but according to the Special Eurobarometer "Science and Technology" from 2010, as much as 87 percent of the Norwegian population support scientific research even though research in itself does not result in any obvious immediate benefits. This percentage is higher than any other country in the survey (European Commission 2010). In recent years, the focus has been on children and youth, not least because they are an important recruiting ground for the STEM-fields. In 1974, 7.4 percent of the population had a university or college 


\section{$\$$}

NORDIC JOURNAL

of Science and Technology Studies

education. By 2012, this had increased to 29.8 percent of those aged 16 and above. Throughout the whole period, with few exceptions it has been difficult to ensure satisfactory recruitment to the STEMfields. Among employees aged between 25 and 34, only 1 percent have STEM-training, whereas the OECD mean is 1.6 percent $(\underline{K D}$ 2010). Consequently, several new activities are planned in order to improve recruitment in those fields, among them strengthening the Science Centres Programme and the Energy-Programme at selected schools (2012-2013:37, 63 \& 99).

Over time, the dissemination model has been enriched by a movement from PAST-measures toward CUSP-measures. At the same time, the dissemination model was challenged by fundamental changes in the role of science in society. Slagstad (2006) maintains that new knowledge regimes emerge and that knowledge is taken into use in new ways in order to promote an extensive modernization. A simple illustration of this change is to be found in the relationship between basic science, applied science, and experimental development as the Frascati Manual defines these categories. If we look at the relative strength of these three categories in Norwegian universities and colleges, it is particularly applied science that has grown constantly and evenly throughout the last half-century (NFR Ongoing). The growth has also substantiated a greater emphasis on user-oriented science communication and thereby strengthened the basis for the dialogical turn, not least because the public and users have more apparent roles within applied research.

\section{The dialogue model}

Already in the 1975-1976 white paper, the user of the research is introduced as an involved actor who can obtain more out of research if channels for two-way communication are established (1975-1976:79). Five reasons for two-way communication are given: 1 ) the researchers get corrective feedback and ideas; 2 ) the users get an opportunity to participate; 3 ) the research results are more easily accepted by the users and adopted if relevant; 4) both researchers and users enrich their knowledge; and finally 5) the users get a better understanding of certainty and uncertainty when interpreting the results. The coming white papers mention dialogue activities and introduces, for example, trainee-programs (1980-1981:47). However, the 1992-1993 white paper introduces the user as a much more active participant. This implies a clearer profile of science communication policy and increased emphasis on the application perspective (1992-1993:148-153) whereas, it is simultaneously emphasized that the acquirement of expertise is primarily the responsibility of the user (1992-1993:148). In the white paper, mention is also made of the Norwegian Biotechnology Advisory Board, established in 1991 (1992-1993:117). Biotechnology was presented as being of special significance concerning security and risk assessment. Important tasks include informing the public administration, and, not least, stimulation to debate in matters of science ethics. The Board has a broad basis in professionals, users, and lay people. The 1998-1999 white paper also attached importance to dialogue in various ways. It is emphasized that dissemination and application can be more difficult when those who are to apply the results have not participated in the research process (1998-1999:83). The authorities therefore recognized the need for new forums, and, in 1999, they established the Norwegian Board of Technology (1998-1999:123). The Norwegian Board of Technology was to determine the possibilities and consequences of new technology, for both society and the individual citizen. The results were to be made known to Parliament as well as to other authorities and the public. At the same time, the Board was to encourage actively public debate on technology. The Board would determine the specific areas for discussion and its working methods.

However, importance was to be attached to methods by which lay people would be engaged in the activities. The Norwegian Board of Technology today employs a number of working methods, such as lay peoples' conferences, workshops, citizen's panels, and hearings. In other words, the authorities wish to engage the public in a more comprehensive technological debate.

The dialogue model assumes what Collins and Evans call "interactional expertise" (2007). Interactional expertise was defined by Evans and Collins by means of an illustration. They write, "if 'talking the talk' corresponds to primary source knowledge (knowing what has to be said), and 'walking the walk' corresponds to contributory expertise (actually being able to perform the task), the interactional expertise corresponds to 'walking the talk' - that is, being able to use the language in novel settings in much the same way as a contributory expert might" (Evans and Collins 2010:52). In other words, an interactional expert would be able to express him- or herself concerning a given field of knowledge without necessarily being able to contribute to knowledge within that field. A good example of this is lay peoples' conferences (1998-1999:123). Holding a conference where a lay panel is confronted with a given area of knowledge assumes interactional expertise. Lay peoples' conferences are an attempt to democratize participation. What this implies in practice will vary, however (Nielsen, Lassen, and Sandøe 200z). Nielsen et al. have made a comparative study of three lay peoples' conferences on genes technology in its broadest form in Norway, Denmark, and France. What was especially interesting was that the relationship between that which took place at the conference and the major question of democracy was experienced quite differently in the three countries. In Norway and Denmark, lay people's conferences were seen as a part of the overall democracy. In France, however, lay people's conferences were considered as being directly "incompatible with democracy" (p. 27). Correspondingly, the participation of the lay people was seen quite differently. In France, the lay people are regarded as "les naifs." In Norway, they were accredited with "everyday knowledge" 


\section{N}

NORDIC JOURNAL

of Science and Technology Studies

or "folk knowledge." In Denmark, their contribution was primarily considered as a contribution to "deliberative democracy." The different understandings naturally have different implications for how participants are prepared for participation. In France, much importance is attached to providing knowledge to the participants in what is to be the main subject of the conference; they are to be "semi-experts." In Norway and Denmark, much greater importance is attached to the social skills in preparing the lay panelists to "perform" at the conference vis-à-vis the experts (p. 32). In other words, they are required to acquire considerable interactional expertise in order to be good participants at lay peoples' conferences. The Norwegian informants had the broadest standpoint in this respect. They considered that "lay people could participate in a meaningful way without any prior training or education in the topic in question" (p. 33). In order to be a part of Evans and Collins's picture, they should be able to "walk the talk," and thereby achieve a new role for the public. In the innovation white paper, the role is also extended to include assessments of the different technologies' potential for innovation and economic growth (St. melding no. 7 [2008-2009]:117).

One group of activities mentioned sporadically in the white papers is the various "field trials," such as design experiments, usability trials, and policy experiments (e.g., 1975-1976:19 \& 1992-1993:138 \& 1992-1993:149). Today's society is characterized by experiments with the aim of developing new solutions encompassing many areas of society. Field trials have been discussed in the 1975-1976 white paper, and new learning methods and health issues are mentioned specifically (1975-1976:19). In some areas, trial projects are so widely used that laws and regulations exist governing their activity. Whereas design experiments and usability trials are primarily examples of the dialogue model, policy experiments are, at best, examples of the participation model (Hetland 2011).

\section{The participation model}

In the 1975-1976 white paper, a distinction was made between three target groups for scientific results: researchers, users, and the public (1975-1976:77). What is important here is that user-oriented science communication, and science communication toward the public, is considered within the same policy area. The NRC launched a policy for user-oriented science communication in 1996. The policy underlines that user-oriented science communication requires two-way communication between the researcher and the user, and that the recipient must have the necessary skills and knowledge to make use of the research results. The aim is to empower the users to act. Further, they emphasize that useroriented science communication should substantiate monitoring and evaluation (

Simultaneous to operating with a division of science communication, within the nine white papers, there are grounds to believe that the interplay between the two traditions has important implications for how the participation model develops over time. User-oriented science communication is built on a long tradition in the Nordic countries (Iydén 1223), and over time, the dialogue with users develops into a full-fledged participation model. This model has its roots in the modernization of agriculture, simultaneous to new communication technology opening up for new interactive possibilities. In a number of white papers, agriculture and "the agricultural extension model" (Rogers 2003:765-166) has been given as an example of the participation model (e.g., 1992-1993:151-152). From the agricultural extension service, field experiments and corresponding arrangements are models of how innovation can originate and spread. Field experiments represent science communication originating in practical agricultural and plant culture trials on members' "own farms." The first trial association in Norway was established in 1937. Agriculture, therefore, has a long history in user-oriented research participation. Within the NRC and Innovation

Norway, a number of measures have been developed that stimulate the commercial aspects, the research activity, and the association between them. The mentioned comprehensive policy area was finally the subject of a separate white paper for innovation policy. The policy measures gradually became so many in number that the white papers discuss modern innovation theory as Triple Helix and Mode 2 (Gibloons et al. 1224., Levdesdorff and Etzkowitz 1298, Nowotny, Scott, and Gibbons 2001). Although it should be emphasized that these theories are controversial, it is difficult not to interpret the active policy in the field of science and innovation as being precisely a stimulation of Triple Helix and Mode 2. These theories and concepts become models for much of the political rhetoric. Triple Helix and Mode 2 are stimulated at an early stage through proposals for mobility incentives between the different research communities, producers, and users. It is emphasized on several occasions that dissemination of knowledge is most effective when occurring through mobility and networks. The concept of interaction (e.g., 2004-2005, 2008-2009, 2012-2013 and St. melding no. 7 [2008-2009]) has gradually been attaining a central place in the white papers. In the first decade of the 21st century, an "industrial PhD" was proposed precisely to encourage this interaction (2004-2005:103).

As mentioned the sectoral principle gives the different ministries crucial roles, especially when it comes to user-oriented science communication. Interesting examples of interaction are given by two ministries, the Ministry of Climate and Environment and the Ministry of Health and Care Services. The Ministry of Climate and Environment launched a new service called Artsobservasjoner [Species Observations] through The Norwegian Biodiversity Information Centre in 2008 (MD 2009). It is a digital reporting system open to everybody. From May 2008 to May 2014, 10.5 million observations have been recorded, mostly by lay people. These 
observations are crucial in many respects, and one application is the Species Map Service used by planners and the like. Citizen science is consequently one emerging method of participation (Dickinson and Bonnev 2012). While Species Observation is open to everybody, the health field is frequently more structured, and its meeting places are typically closed. Samspill 2.0 [Interaction 2.0] aims to improve patients', users', and other stakeholder's information about health and health services. Further, patients and users shall have easy access to information about their own health situation and the possibility to participate in their own treatment ( $\underline{H O D} 2010)$. Within citizen science, one important issue is how to identify trustworthy and credible information (Evsenbach 2008, Hetland 2011). Consequently, apomediation is launched as the "third way" by which users can recognize trustworthy information, and thereby it is an important element in promoting the participation model. Both within the private and public sector, the white papers emphasize participation by employees and users (e.g. St. melding no. 7 [2008-2009]:19-29 \& St. melding no. 7 [2008-2009]:126). The participation model aims to involve the different publics in doing science and therefore gives broad possibilities to play out engagement and expertise.

\section{Conclusion}

Policies concerning science communication have gradually changed over time. The most important change concerns the increased importance of dialogue and participation within all three main models. Through an active policy aiming at dialogue, sponsored hybrid forums that encourage participation have gradually been developed. In addition, social media has facilitated an increase in spontaneous public involvement in a correspondingly increasing number of hybrid forums. Dialogue and participation thus become crucial parts of science and technology development. The traditional division between science and science communication was thus challenged by the various forms of dialogue, also within the dissemination model. In other words, we have a

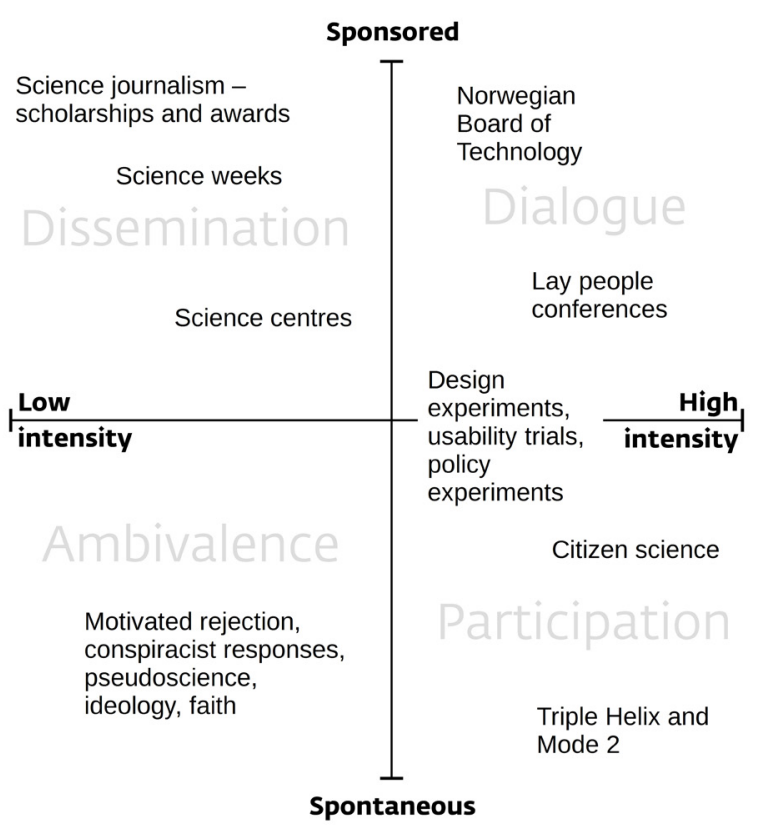

Figure 2. Participation forms for users and the public Source: Modeled after Bucchi 2009:66

broader inventory of types of communication and involvement. Each model therefore constitutes a development zone where policy-makers experiment with the possibility for the public to act out their own expertise in order to enhance engagement. On the basis of the two dimensions, the degree of cooperation and the degree of sponsorship, Bucchi draws a map of public participation in techno-science (Bucchi 2009:66). I will exemplify this map while drawing on some of the policy measures mentioned in the white papers since 1975 (Figure 2).

The upper-left quadrant illustrates policy measures within the dissemination model. The dissemination model experienced notable development during the 1990 s and the first decade of the new century. The competition element was employed both in respect of the lay people and of researchers, thereby increasing the possibilities for engagement. The popularized news-flow is increasing rapidly, not least because of the establishment of the online newspaper forskning.no, including both many bloggers and the possibility for discussing the news presented. Further, Norway is steadily acquiring more competent science journalists. Both the more traditional and newer media are attaining feedback channels. There is much to suggest that multisource journalism is increasing both generally and as issues become more domesticated (Hetland 2012). Both processes give the public greater opportunity for engagement. Science centers and museums are adopting social media, increasing the possibilities for inquiry-based learning. The political attention on science communication has resulted in the motto "to be seen in public or perish" being taken seriously by researchers and institutions. The dissemination model consequently remains an important communication model, a finding that is also well documented by Brossard and Lewenstein (2010). Activities within the dissemination model invite the public to participate in a process where knowledge building is of a more general character. The expertise acquired by users is primarily that which Collins and Evans call "popular understanding" and "primary source knowledge" ( $\underline{\text { Collins }}$ and Evans 2007:19-23). Over time, there has been an interesting movement from PAST-measures to CUSP-measures within dissemination activities. The movement is apparent in some of the policy measures suggested and implemented. 


\section{N}

NORDIC JOURNAL

of Science and Technology Studies

The upper-right quadrant represents policy measures within the dialogue model. The dialogue model, which aims to bridge the single delegation and extend the peer community, was developed as a policy model in the 1990s. Experimentation had already become a central work form in modern society, and increasing numbers of persons are becoming acquainted with science and technology through reform activities and the more formative experiments to manage social change. Within the dialogue model, we therefore find a number of activities because of clear political initiative involving the public and users. What characterizes these activities is that they represent an extension of democracy in forms such as the Norwegian Board of Technology and lay peoples' conferences. It is maintained that participation is important in order to ensure the development of knowledge, good risk assessment, and diffusion of innovations. However, it can also be claimed that the construction of different publics is an inherent weakness within the dialogue model (Braun and Schultz 2010), and that the model therefore gives opportunities for playing out participation and expertise within rather predefined frames. The fact that, according to Braun and Schultz, such groups are not authentic publics, but pure publics shaped by practices and settings, limits the speaking positions available. The expertise with which users contribute is primarily what Collins and Evans call "interactional expertise" (Collins and Evans 2007:28-40) but with elements of "contributory expertise" (2007:24-2z).

The lower-right quadrant represents policy measures within the participation model. The participation model in general, which aims to bridge the double delegation, has its roots in the agricultural extension model as a highly successful model based on "client participation in identifying local needs, planning programs, and in performing evaluation and feedback" (Rogers 2003:304), and it has developed along two tracks. First, central to innovation policy was the inclusion of a steadily increasing number of innovation measures. Participation thus became important to shape innovations and promote diffusion. Second, social media has enabled participation in completely new ways, enabling virtual collaboration. Examples such as biodiversity mapping with the aid of species observation and patients' participation illustrate the new possibilities for exercising citizen science. The fact that public authorities undertake special responsibility for establishing boundary infrastructures, as the Species Observations, also facilitates the participation of lay people in knowledge building in new ways (Bowker and Star 1222). Participation is linked either to collaborative knowledge building, which assumes communal effort within the general sphere of knowledge, or because the user has a genuine user skill and is a central player in constructing his or her own activity, health, and welfare. The participation model involves both the "affected public" and the "partisan public" (Braun and Schultz 2010) - that is a public that is either affected by the issue at hand or different kinds of interest groups. Consequently, the participation model opens the broadest possibilities to play out participation and expertise. The expertise with which users contribute is primarily that which Collins and Evans call "contributory expertise" (2007:24-27).

Finally, there is the "science and technology ambivalence" quadrant. Science and technology ambivalence is almost never mentioned explicitly in Norwegian science communication policy, but it is frequently implicit as an important reason for promoting science communication at all.

A review of Norwegian science communication policy clearly reveals how at a policy level concerns with public engagement over time have led to a mode that is more dialogical across the three models within science and technology communication policy. Involvement is regarded as important to ensure democratic participation, a broad participation associated with assessment of risk and ethics, exchange of knowledge, and knowledge building, as well as the encouragement of innovation and its diffusion. The growing importance of dialogue and participation is also an indicator of a weakening importance of Ingelfinger's rule. Those participating represent user interests, the need to stimulate debate, but also a genuine desire to develop and contribute with one's own expertise. Participation is organized along two dimensions: a) intensity of knowledge building, and b) whether the hybrid forums are sponsored or spontaneous. The two dimensions open up for an interesting variation of participation forms. When ideas on participation "migrate," an interpretation often occurs that adapts the participation form to fit a local context - a good example being lay people's conferences. Participation is consequently grounded in an increasingly number of hybrid forums shaped by local context.

Per Hetland (PhD) is associate professor at Department of Education, University of Oslo. His research centers on science and technology studies, especially public communication of science and technology. He is currently working on two projects: the first about blended learning and virtual ethnography and the second about the use of multimedia in special needs education and rehabilitation in East-Africa.

\section{Acknowledgment}

I am grateful to colleagues at the research group InterMedia and the two anonymous reviewers for their comments.

Alme, P. 1995. "Forskningsresultater må formidles!" Aftenposten, November 6 . 
Andersen, E. K., and H. Hornmoen. 2011. Mediating Science in Norway: Practices and Transformations in Major Newspapers. Media Transformations 5:88-104.

Bauer, M. W., and M. Bucchi, eds. 2007. Journalism, Science and Society: Science Communication between News and Public Relations. New York: Routledge.

Bech-Karlsen, J. 1996. Ubehaget i journalistikken. Oslo: Forlaget Forum.

Bentley, P., and S. Kyvik. 2011. Academic staff and public communication: a survey of popular science publishing across 13 countries. Public Understanding of Science 20 (1):48-63.

Bowker, G., and S. L. Star. 1999. Sorting Things Out: Classification and its Concequences. Cambridge, Massachusetts: The MIT Press.

Braun, K., and S. Schultz. 2010. "... a certain amount of engineering involved": Constructing the public in participatory goverance arrangements. Public Understanding of Science 19 (4):403-419.

Brint, S., and A. M. Cantwell. 2012. Portrait of the disengaged. In Research \& Occasional Paper Series: CSHE.9.12. Berkeley: University of California.

Broks, P. 2006. Understanding Popular Science. Maidenhead: Open University Press.

Brossard, D., and B. V. Lewenstein. 2010. A Critical Appraisal of Models of Public Understanding of Science. In L. Kahlor and P. A. Stout (eds.) Communicating Science: New Agendas in Communication: 11-39. New York: Routledge.

Bucchi, M. 2009. Beyond Technocracy: Science, Politics and Citizens. Dordrecht: Springer.

Bucchi, M., and B. Trench, eds. 2008. Handbook of Public Communication of Science and Technology. London: Routledge.

Callon, M. 1999. The Role of Lay People in the Production and Dissemination of Scientific Knowledge. Science, Technology \& Society 4 (1):81-94.

Callon, M., P. Lascoumes, and Y. Barthe. 2009. Acting in an Uncertain World: An Essay on Technical Democracy. Cambridge. Massachusetts: The MIT Press.

Collins, H., and R. Evans. 2007. Rethinking Expertise. Chicago: The University of Chicago Press.

Delgado, A., K. L. Kjølberg, and F. Wickson. 2011. Public engagement coming of age: From theory to practice in STS encounters with nanotechnology. Public Understanding of Science 20 (6):826-845.
Dickinson, J. L., and R. Bonney, eds. 2012. Citizen Science: Public Participation in Environmental Research. Ithaca: Comstock Publishing Associates.

Eide, M., and R. Ottosen. 1994. "Science journalism" without science journalists: notes on a Norwegian media paradox. Public Understanding of Science 3 (4):425-434.

European Commission. 2010. Special Eurobarometer - Science and Technology Report.

Evans, R., and H. Collins. 2010. Interactional Expertise and the Imitation Game. In M. E. Gorman (ed.) Trading Zones and Interactional Expertise: 53-70. Cambridge, MA: The MIT Press.

Eysenbach, G. 2008. Medicine 2.0: Social Networking, Collaboration, Participation, Apomediation, and Openness. Journal of Medical Internet Research 10 (3):1-9.

FAD. 1978. Offentlig informasjon. edited by Forbruker- og administrasjonsdepartementet. Oslo.

FAD. 2009. Statens kommunikasjonspolitikk. edited by Fornyings- og administrasjonsdepartementet. Oslo.

Fagerberg, J., D. C. Mowery, and R. R. Nelson, eds. 2005. The Oxford Handbook of Innovation. Oxford: Oxford University Press.

Finne, H., and P. Hetland. 2005. Meritteringssystemer i FoUsektoren i forhold til nærings- og innovasjonsrettet FoUvirksomhet. In Arbeidsnotat. Oslo: Nordic Institute for Studies in Innovation, Research and Education.

Funtowicz, S. O., and J. R. Ravetz. 1992. Three types of risk assessment and the emergence of postnormal science. In S. Krimsky and D. Golding (eds.) Social theories of risk: 251-274. Westport, Conn.: Praeger.

Gibbons, M., C. Limoges, H. Nowotny, S. Schwartzman, P. Scott, and M. Trow. 1994. The New Production of Knowledge: The dynamics of science and research in contemporary societies. London: Sage.

Gieryn, T. F. 1999. Cultural Boundaries of Science. Chicago: The University of Chicago Press.

Hess, D. J. 2011. To tell the truth: on scientific counterpublics. Public Understanding of Science 20 (5):627-641.

Hetland, P. 1996. Exploring Hybrid Communities: Telecommunication on Trial. PhD, Department of Media and Communication, University of Oslo.

Hetland, P. 2011. Science 2.0: Bridging Science and the Public. Nordic Journal of Digital Literacy 6 (Special Issue):326-339. 
Hetland, P. 2012. Internet between Utopia and Dystopia: The Narratives of Control. Nordicom Review 33 (2):3-15.

Hilgartner, S. 1990. The Dominant View of Popularization: Conceptual Problems, Political Uses. Social Studies of Science 20 (3):519-539.

HOD. 2010. Samspill 2.0: Nasjonal strategi for elektronisk samspill i helse- og omsorgssektoren 2008-2013. Helse- og omsorgsdepartementet. Oslo.

Holm, E. D. 2000. Da forskningen forlot parnasset - fortellingen om formidlingen fra KULT. Oslo: Pax Forlag.

Informasjonsutvalget. 1962. Innstilling fra informasjonsutvalget. edited by Finans- og tolldepartementet. Oslo.

Irwin, A., and M. Michael. 2003. Science, Social Theory and Public Knowledge. Maidenhead: Open University Press.

Kallerud, E., T. Finnbjørnsson, L. Geschwind, M. Häyrinen-Alestalo, I. Ramberg, K. Siuene, and T. Tuominen. 2011. Public Debate on Research Policy in the Nordic Countries: A Comparative Analysis of Actors and Issues (1998-2007). Oslo: Nordic Institute for Studies in Innovation, Research and Education.

Kasperowski, D., and F. Bragesjö. 2011. Bilda och samverka - om införandet, implementering och förändringen av universitetens tredje uppgift 1977-1997. Göteborgs Universitet: Institutionen för filosofi, lingvistik och vetenskapsteori.

KD. 2010. Realfag for framtida - Strategi for styrking av realfag og teknologi 2010-2014. edited by Kunnskapsdepartementet. Oslo.

Kyvik, S. 2005. Popular Science Publishing and Contributions to Public Discourse among University Faculty. Science Communication 26 (3):288-311.

Lasswell, H. 1948. The structure and function of communication in society. In L. Bryson (ed.) The Communication of Ideas. New York: Institute for Religious and Social Studies.

Le Marec, J., and I. Babou. 2008. Word and Figures of the Public: the Misunderstanding in Scientific Communication. In D. Cheng, M. Claessens, T. Gascoigne, J. Metcalfe, B. Schiele and S. Shi (eds.) Communicating Science in Social Contexts: 39-54. Springer Science.

Lewandowsky, S., K. Oberauer, and G. Gignac. 2013. NASA faked the moon landing - Therefore (Climate) Science is a Hoax: An Anatomy of the Motivated Rejection of Science. Psychological Science 24 (5):622-633.

Leydesdorff, L., and H. Etzkowitz. 1998. The Triple Helix as a Model for Innovation Studies. Science \& Public Policy 25 (3):195-203.
Løvhaug, J. W. 2011. Overlæreren i rampelyset: Universitetet i mediesamfunnet 1970-2011. In J. P. Collett (ed.) Universitetet i Oslo 1811-2011. OsIo: UNIPUB.

MD. 2009. Norway's National Report on Implementation of the Convention on Biological Diversity. edited by Miljødepartementet. Oslo.

Nelkin, D. 1995. Selling Science. How Press Covers Science and Technology. New York: W. H. Freeman and Company.

NFR. 1996. Strategi for forskningsformidling med hovedvekt på brukerrettet formidling. Oslo: Norges forskningsråd.

NFR. 1997. Nasjonal strategi for allmennrettet forskningsformidling. Oslo: Norges forskningsråd.

NFR. Ongoing. Science and Technology Indicators for Norway. Norges forskningsråd.

Nielsen, A. P., J. Lassen, and P. Sandøe. 2007. Democracy at its best? The Consensus Conference in a Cross-National Perspective. Journal of Agricultural and Environmental Ethics 2007 (20):13-35.

Nowotny, H., P. Scott, and M. Gibbons. 2001. Re-thinking science: Knowledge and the public in an age of uncertainty. Cambridge: Polity Press.

Perrault, S. T. 2013. Communicating Popular Science: From Deficit to Democracy. New York: Palgrave Macmillan.

Rip, A. 2003. Societal challenges for R\&D evaluation. In P. Shapira and S. Kuhlmann (eds.) Learning from Science and Technology Policy Evaluation: 32-53. Cheltenham: Edward Elgar.

Rogers, E. M. 2003. Diffusion of Innovations. New York: Free Press.

Skoie, H. 2005. Norsk forskningspolitikk i etterkrigsstiden. Oslo: Cappelen Akademisk Forlag.

Slagstad, R. 2006. Kunnskapens hus. Oslo: Pax Forlag.

Snow, C. P. 1963. The Two Cultures: A Second Look. Cambridge: Cambridge University Press.

Suerdem, A., M. W. Bauer, S. Howard, and L. Ruby. 2013. PUS in turbulent times II - A shifting vocabulary that brokers inter-disciplinary knowledge. Public Understanding of Science 22 (1):2-15.

Toy, J. 2002. The Ingelfinger Rule: Franz Ingelfinger at the New England Journal of Medicine 1967-1977. Science Editor 25 (6):195-98.

Trench, B. 2008. Towards an Analytical Framework of Science Communication Models. In D. Cheng, M. Claessens, T. Gascoigne, J. 
Metcalfe, B. Schiele and S. Shi (eds.) Communicating Science in Social Contexts: New models, new practices: 119-135. Netherlands: Springer Science+Business Media B.V.

Tydén, T. 1993. Knowledge Interplay - User-Oriented Research Dissemination through Synthesis Pedagogics. PhD, Uppsala University (Uppsala Studies in Education).
UHR. 2005. Sammen om kunnskap - Nytt system for dokumentasjon av formidling. UHRs formidlingsutvalg til UFD. Oslo.

UHR. 2006. Sammen om kunnskap II - Operasjonalisering av indikatorer for formidling. UHRs formidlingsutvalg II til KD. Oslo.

Väliverronen, E. 1993. Science and the media: changing relations. Science Studies 6:23-34. 